\title{
Postnatal Transitions in Noradrenaline- induced Glycogenolysis and Lipid Mobilization in Newborn Calves
}

\author{
Hiroshi Sato, Teruhisa Imamura and Shogo Hanasaka \\ Tohoku National Agricultural Experiment Station, \\ Morioka-shi, $020-01$
}

(Received May 6, 1981)

\begin{abstract}
In Holstein calves, noradrenaline (NA) was infused intravenously at a dose rate of $4 \mu \mathrm{g} / \mathrm{kg} / \mathrm{min}$ for $30 \min$ at $1,8,18,30$ and 45 days of age, and blood samples were taken before and after the infusion to estimate the postnatal transition of liver glycogenolysis and adipose tissue lipolysis. Elevations of packed cell volume (PCV), plasma glucose and free fatty acid (FFA) levels after NA infusion were significantly lower at young stages, but there was no significant difference in elevation of plasma free glycerol (FG) level among the postnatal stages. At younger stages, FFA/FG ratio after NA infusion was significantly lower than that at older stages. It is considered that slight increases in PCV and glucose level after NA infusion at young stages may be due to immature sympathetic development, and a slight rise in plasma FFA level may be owing to accelerated re-esterification or oxidation of released FFA within the adipose tissue, but not to weak lipolysis. Jpn. J. Zootech. Sci., 52 (12): $878-881,1981$
\end{abstract}

It has been well known that triglyceride storage in the adipose tissue and liver glycogen are mobilized rapidly by sympathetic activation or catecholamine injection in many animals. In young calves, the hyperglycemic response to sympathetic stimulus is more pronounced with advancing age $\mathrm{e}^{1-3}$. Similarly, the elevation of plasma free fatty acid (FFA) level after noradrenaline (NA) injection in calves ${ }^{4}$ and after cold exposure in lambs ${ }^{5)}$ is also more accelerated with advancing age. At younger stages, however, NA-induced elevation of metabolic rate $\left(\mathrm{O}_{2}\right.$ consumption) is extremely higher than that at older stages in calves $^{6\rangle}$ and $\operatorname{lambs}^{7,8)}$. In the present study, NA was infused intravenously to 1-45 days old calves, and postnatal developments of liver glycogenolysis and lipid mobilization were estimated.

\section{Materials and Methods}

Four newborn Holstein calves of both sexes were used. They weighed $45-52 \mathrm{~kg}$ at birth, and suckled colostrum from their dams during the first few days after birth, then they were fed $6 \mathrm{~kg}$ of whole milk daily, and hay was given freely. Glycogenolytic and lipolytic responses to exogenous NA were estimated at 1 (16-28 hrs), 8, 18, 30 and 45 days after birth. At 1-day age, the calves were transfered to individual calf pens at 5-7 hrs before the experiment started, and on the morning of the other stages of experiments, no milk was given. During the 45 days' period, they grew normally and showed the weight gain of $18-26 \mathrm{~kg}$. 
Using an indwelling catheter previously inserted into the jugular vein, NA (dlnoradrenaline, Sankyo Co.) was infused continuously at a dose rate of $4 \mu \mathrm{g} / \mathrm{kg}$ (body weight) $/ \mathrm{min}$ for $30 \mathrm{~min}$, and blood samples were collected into a heparinized tube before and immediately after the infusion. The blood samples were chilled by ice, and after centrifugation, plasma samples were stored at $-20^{\circ} \mathrm{C}$ till analysis. Plasma glucose and free glycerol (FG) were analyzed by enzymatic procedures (Blood SugarGOD-Test, Glycerol-Neutralfat UV Test; Boehringer Mannheim Corp.). Plasma FFA was estimated by colorimetric method", and packed cell volume (PCV) was determined by microhaematocrit capillary tube.

\section{Results and Discussion}

Dose rate of NA in the present experiment $(120 \mu \mathrm{g} / \mathrm{kg}$ for $30 \mathrm{~min})$ was extremely higher than that in dairy cows $(5-7 \mu \mathrm{g} / \mathrm{kg})^{10)}$ and in adult sheep $(8 \mu \mathrm{g} / \mathrm{kg})^{11}$. It was recognized, however, that plasma FFA level in neonatal lambs failed to increase following the injection of NA in the amounts which elevated FFA level in ewes ${ }^{12}$. ALEXANDER and coworkers also infused NA to newborn calves ${ }^{6)}$ and lambs $^{7)}$ at a similar dose rate as the present experiment. No abnormality was observed visually after the infusion.

Infusion of NA caused a significant increase in each measurement of PCV and plasma metabolite levels (Table 1). Elevations of PCV and plasma glucose level by NA infusion were apparently pronounced with advancing age. EDWARDS ${ }^{2)}$ also reported that the elevations of PCV and plasma glucose level following splanchnic stimulation were considerably small in newborn calves. He mentioned that the hyperglycemic response to splanchnic stimulation in the calf might be directly dependent upon the hepatic sympathetic innervation. Moreover, it is known that the innervation of the adrenal medulla is still undeveloped in newborn calves ${ }^{13)}$, so it is considered that the sympathetic innervation of the spleen and liver may also be relatively immature at the early stage of growth. In the previous study ${ }^{4}$, however, hyperglycemic response to subcutaneously injected NA was greater at younger than at older stages. The inconsistency with the present results might be owing to delayed absorption of the subcutaneously injected NA and its sustained glycogenolytic action at younger stages. Higher plasma glucose level (pre-infusion) at 1 day of age may be possibly associated with suckling colostrum 5-7 hrs before the experiment.

Increase in FFA level by NA infusion was significantly smaller at younger stages than at older ones, while, there was no significant difference among the calves' ages in NA-induced elevation of FG level. At 1 day of age, plasma FG level before the infusion was higher and FFA/FG ratio was lower than those at older stages. At younger stages, FFA/FG ratio and a ratio of increments in plasma FFA and FG $(\Delta \mathrm{FFA} / \Delta \mathrm{FG})$ after $\mathrm{NA}$ infusion were also smaller than those at older stages.

Catecholamine stimulates the lipolysis of triglyceride store, and releases FFA and FG from the adipose tissue. The full extent of FFA mobilization may somewhat masked by re-esterification and mitochondrial oxidation of FFA within the adipocyte ${ }^{14}$, 
Table 1. Changes in PCV and plasma metabolite levels after intravenous infusion of NA at a dose rate of $4 \mu \mathrm{g} / \mathrm{kg} / \mathrm{min}$ for $30 \mathrm{~min}$ in young calves

\begin{tabular}{|c|c|c|c|c|c|c|}
\hline & & \multicolumn{4}{|c|}{ Age (days) } & \\
\hline & & 1 & 8 & 18 & 30 & 45 \\
\hline \multirow[t]{3}{*}{$\begin{array}{r}\mathrm{PCV} \\
(\%)\end{array}$} & $\begin{array}{l}\text { Pre- } \\
\text { infusion }\end{array}$ & $30.5 \pm 1.5$ & $28.7 \pm 1.4$ & $32.1 \pm 2.7$ & $34.4 \pm 2.4$ & $33.3 \pm 2.1$ \\
\hline & $\begin{array}{l}\text { Post- } \\
\text { infusion }\end{array}$ & $32.3^{a} \pm 1.0$ & $32.9^{a} \pm 1.6$ & $39.8^{a b} \pm 3.7$ & $43.1^{b} \pm 3.1$ & $41.6^{b} \pm 2.6$ \\
\hline & $\Delta$ & $1.8^{a} \pm 0.5$ & $4.2^{b} \pm 0.3$ & $7.6^{c} \pm 1.0$ & $8.7^{c} \pm 1.0$ & $8.3^{c} \pm 1.0$ \\
\hline \multirow[t]{3}{*}{$\begin{array}{r}\text { Glucose } \\
(\mathrm{mM})\end{array}$} & Pre- & $5.84^{a} \pm 0.37$ & $5.04^{\mathrm{ab}} \pm 0.14$ & $4.73^{b} \pm 0.33$ & $4.61^{b} \pm 0.26$ & $4.57^{b} \pm 0.31$ \\
\hline & Post- & $10.32 \pm 0.33$ & $10.47 \pm 0.38$ & $10.09 \pm 1.42$ & $10.92 \pm 1.15$ & $12.01 \pm 0.96$ \\
\hline & $\Delta$ & $4.47 \pm 0.45$ & $5.43 \pm 0.42$ & $5.36 \pm 1.12$ & $6.31 \pm 0.94$ & $7.44 \pm 0.67$ \\
\hline \multirow[t]{3}{*}{$\begin{array}{l}\text { FFA } \\
\qquad(\mathrm{mM})\end{array}$} & Pre- & $0.28 \pm 0.04$ & $0.28 \pm 0.05$ & $0.25 \pm 0.07$ & $0.26 \pm 0.03$ & $0.26 \pm 0.03$ \\
\hline & Post- & $0.98^{a} \pm 0.06$ & $1.19^{b} \pm 0.07$ & $1.49^{c} \pm 0.05$ & $1.71^{d} \pm 0.05$ & $1.74^{\mathrm{d}} \pm 0.06$ \\
\hline & $\Delta$ & $0.70^{a} \pm 0.05$ & $0.91^{b} \pm 0.04$ & $1.24^{\mathrm{c}} \pm 0.03$ & $1.46^{\mathrm{d}} \pm 0.08$ & $1.48^{\mathrm{d}} \pm 0.06$ \\
\hline \multirow[t]{3}{*}{$\mathrm{FG}(\mathrm{mM})$} & Pre- & $0.13^{a} \pm 0.02$ & $0.08^{b} \pm 0.01$ & $0.07^{b} \pm 0.01$ & $0.08^{b} \pm 0.01$ & $0.08^{b} \pm 0.01$ \\
\hline & Post- & $0.33 \pm 0.05$ & $0.24 \pm 0.02$ & $0.25 \pm 0.01$ & $0.28 \pm 0.01$ & $0.30 \pm 0.02$ \\
\hline & $\Delta$ & $0.20 \pm 0.03$ & $0.16 \pm 0.01$ & $0.18 \pm 0.01$ & $0.21 \pm 0.01$ & $0.22 \pm 0.02$ \\
\hline \multirow[t]{2}{*}{$\mathrm{FFA} / \mathrm{FG}$} & Pre- & $2.20 \pm 0.30$ & $3.43 \pm 0.56$ & $3.48 \pm 0.90$ & $3.72 \pm 0.73$ & $3.87 \pm 0.92$ \\
\hline & Post- & $3.12^{\mathrm{a}} \pm 0.43$ & $4.96^{b} \pm 0.52$ & $5.93^{\mathrm{b}} \pm 0.21$ & $6.06^{6} \pm 0.18$ & $5.95^{b} \pm 0.60$ \\
\hline \multicolumn{2}{|c|}{$\Delta \mathrm{FFA} / \Delta \mathrm{FG}$} & $3.80^{a} \pm 0.68$ & $5.71^{b} \pm 0.57$ & $7.08^{b} \pm 0.32$ & $7.04^{b} \pm 0.46$ & $6.79^{b} \pm 0.73$ \\
\hline
\end{tabular}

Mean $\pm S E(n=4)$. There are significant differences among the means not having the same superscript letters $(\mathrm{P}<0.05)$.

however, most of the released FG is diffused into the blood owing to little utilization of FG in the adipose tissue ${ }^{15}$. High FG level (pre-infusion) at 1 day of age indicates a greater hydrolysis of triglyceride store in newly born calves. It is recognized that $\mathrm{FFA} / \mathrm{FG}$ ratio and $\triangle \mathrm{FFA} / \Delta \mathrm{FG}$ ratio are good indication of the relative rate of lipolysis and re-esterification, i. e., increased re-esterification causes a fall in those ratio ${ }^{16.17)}$. Therefore, it seemed likely that the small increase in FFA level after NA infusion at younger stages might not be due to weak lipolysis, but to the acceleration of re-esterification and FFA oxidation within the adipose tissue or to the increased utilization of FFA by the other tissues.

\section{References}

1) Edwards, A. V. and M. Sulver, J. Physiol., 211: 109-124. 1970.

2) Edwards, A. V. J. Physiol., 220: 315-334. 1972.

3) Bloom, S. R., A. V. Edwards and N. J. A. Vaughan, J. Physiol., 233: 457-466. 1973.

4) Sato, H., S. Hanasaka and T. Imamura, Jpn. J. Zootech. Sci., 52: 467 471. 1981.

5) Al.exander, G., S. C. Mills and T.W.Scott, J. Physiol., 198: 277-289. 1968.

6) Alexander, G., J. W. Bennett and R. T. Gemmell, J. Physiol, 244: 223-234. 1975.

7) Alexander, G. Biol. Neonat., 14: 97-106. 1969.

8) Thompson, G. E. and D. M. Jenkison, Canad. J. Physiol. Pharmacol., 47: 249-253. 1969.

9) ItAYA, K. and M. UI, J, Lipid. Res., 6: 16-20. 1965 ,

10) Sato, H. Jpn. J. Zootech. Sci., 48: 610-616. 1977. 
Glycogenolysis and Lipolysis in Newborn Calves

11) Luthman, J. and G. Jonson, Acta Vet. Scand,, 10: 168-180. 1969.

12) Van Duyne, C., H. R. Parker and L. W. Holm, Am. J. Obst. Gynecol., 91: 277-285. 1965.

13) Comline, R. S. and M. Silver, Brit. Med. Bull, 22: 16-20. 1966.

14) Nicholls, D. G., Biochem. Soc. Trans., 5: 908-912. 1977.

15) Harper, H.A. and P. Mayes, in Review of Physiological Chemistry, 15 th ed. (Harper, H. A. ed.). 301. Maruzen, Tokyo. 1975.

16) Metz, S. H. M. and S. G. Van Den Bergh, Neth. J. Agric. Sci, 25: 198-211. 1977.

17) OradA, K. and C. NaIto, Folia Endocr. Jpn., 50: 1065-1066, 1115 1133. 1974.

\title{
新生子牛におけるノルアドレナリン投与後の \\ グリコーゲン分解と脂肪動員の生後推移
}

\author{
佐藤 博・今村照久・花坂昭吾
}

柬北農業試験場，盛岡市 020-01

子牛のグリコーダン分解之脂肪動員の生後発達の機楆

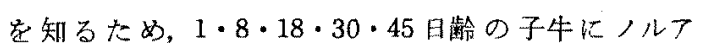
ドレナリン (NA) 静脈内注入し $(4 \mu \mathrm{g} / \mathrm{kg} /$ 分で 30 分

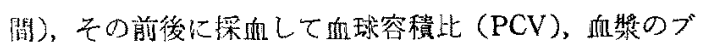
ドウ糖・遊離脂肪酸 (FFA)・遊離グリセロール（FG） 濃度の変化を調ベた、NA 社入後の PCV・ブドウ結・ FFA 濃度の上早は若齢時ほど小さかったが、FG 漕度の
上昇には日齢による差がなく，NA 投与後の FFA/FG 此恬若龄時に低かった．NA 注入後の PCVやブドウ糖 濃度の上昇が苦齢時に小さいのは交感神経系の未発達に 関係があり，また脂肪組織内で FFA の再エステル化あ るいは酸化が充進しているため，若龄時には血装 FFA 濃度の上昇が小さいと考えられた。

日篢会報，52(12)：878-881，1981 